\title{
Slag Splashing in a Basic Oxygen Furnace under Different Blowing Conditions
}

\author{
Miguel A. Barron, Isaias Hilerio, Dulce Y. Medina \\ Departamento de Materiales, Universidad Autonoma Metropolitana Azcapotzalco, Mexico, D.F., Mexico \\ Email:bmma@correo.azc.uam.mx
}

Received 30 November 2015; accepted 22 December 2015; published 25 December 2015

Copyright (C) 2015 by authors and Scientific Research Publishing Inc.

This work is licensed under the Creative Commons Attribution International License (CC BY).

http://creativecommons.org/licenses/by/4.0/

(c) (i) Open Access

\begin{abstract}
The influence of three different blowing conditions on the slag splashing process in a basic oxygen furnace for steelmaking is analyzed here using two-dimensional transient Computational Fluid Dynamics simulations. Four blowing conditions are considered in the computer runs: top blowing, combined blowing using just a bottom centered nozzle, combined blowing using two bottom lateral nozzles, and full combined blowing using the three top and the three bottom nozzles. Computer simulations show that full combined blowing provides greater slag splashing than conventional top blowing.
\end{abstract}

\section{Keywords}

Basic Oxygen Furnace, Bottom Blowing, Combined Blowing, Computational Fluid Dynamics, Oxygen Steelmaking, Refractory Lining, Slag Splashing, Top Blowing

\section{Introduction}

Around two thirds of the world raw steel is produced by means of the basic oxygen furnace (BOF) process. In this process, impurities of molten iron are removed by oxidation with gaseous oxygen which is blown through a top lance or bottom tuyeres. Top blowing at supersonic speed has been the dominating mode of oxygen jet injection since the beginning of the BOF technology. On the other hand, combined blowing, or simultaneous top and bottom blowing, is a blowing condition that allows more agitation in the metal bath, yields fast decarburization rate, accelerated removal of impurities and chemical and thermal homogenization.

Currently, wear of refractory lining in basic oxygen furnaces for raw steel manufacturing is a factor which exerts a significant influence on the production costs in actual industrial steelmaking plants. Since around two decades ago, slag splashing has emerged as a new technology focused to extend the lifetime of the refractory lining of BOF. Slag splashing reduces the wear associated to thermal and chemical attack by molten slag, and gives protection against mechanical impact by solid scrap [1]. In the slag splashing process, molten slag remaining 
in the BOF bottom after the draining of steel is splashed to the converter sidewalls by means of a nitrogen jet. Later, molten slag freezes at the converter walls and forms a protective coating that helps to decrease the wear of the refractory lining. Nitrogen is injected into the converter through a water-cooled vertical lance and bottom tuyeres. The momentum of the nitrogen jets is transferred to the slag, which causes the slag to be stirred and ejected by the action of a standing wave and high shear forces, respectively.

Three stages are present in the formation of the slag coating: 1) transport of molten slag to the converter walls, 2) adherence of the molten slag to the sidewalls, and 3) freezing and hardening of the slag layer [2]. Related to the transport of the molten slag to the converter sidewalls, two mechanisms are identified: washing coating, and ejection coating [3]. The first one occurs due to the bulk movement of the molten slag to rise above the initial level, and the second one due to the ejection of slag droplets which adhere to the vessel sidewalls [4].

Several studies employing physical scale models of the BOF in which cold water and air replace molten slag and nitrogen, respectively, are reported [3] [5] [6]. Reported results are as follows: large nozzle inclination and lance heights increase the splashing, and the main mechanism of splashing changes from ejection to washing as the viscosity of the liquid is increased [3]; the amount of slag splashed is increased as lance is raised, but beyond at a critical value of the lance height splashing decreases [5]; when the jet flow rate is increased or the liquid viscosity is decreased, the lower regions of the walls are splashed at a much greater rate [6]; by changing the lance height, more liquid is deposited in the upper regions of the vessel at the expense of lower regions [6].

Some of the authors of the present work have published recent papers in which the influence of the operating conditions [7] and the molten slag properties [8] [9] on the splashing efficiency is analyzed. Here, the influence of the kind of blowing on the slag splashing is studied using transient two-dimensional Computational Fluid Dynamics (CFD) simulations. Top, bottom, and combined blowing of the nitrogen jet are considered, and results of computer simulations are discussed.

\section{Mathematical Model}

Predominance of the washing or ejection coating mechanisms depends on factors such as the jet characteristics (velocity, exit angle), the operating conditions (lance height, molten slag depth) and the slag properties (viscosity, density, temperature). Inertial, gravitational, viscous and interfacial forces are applied on both phases, i.e. gaseous nitrogen and molten slag, causing a non-isothermal flow. The flow of an incompressible newtonian fluid is governed by the Navier-Stokes equations, which are expressed as [10]:

$$
\frac{\partial\left(\rho u_{i}\right)}{\partial t}+\frac{\partial\left(\rho u_{i} u_{j}\right)}{\partial x_{j}}=-\frac{\partial p}{\partial x_{i}}+\frac{\partial}{\partial x_{j}}\left\{\mu_{e f f}\left(\frac{\partial u_{i}}{\partial x_{j}}+\frac{\partial u_{j}}{\partial x_{i}}\right)\right\}
$$

where $\rho$ is the fluid density, $u_{i}$ is the $i$ component of the fluid velocity $u, t$ is time, $x_{j}$ is $j$ spatial coordinate, $p$ is pressure, and $\mu_{\text {eff }}$ is the effective fluid viscosity. To maintain the mass balance in the system, the continuity equation [7] $\partial u_{j} / \partial x_{j}=0$ is solved. Turbulence is modeled using the $K-\varepsilon$ model [11]:

$$
\begin{gathered}
\rho v_{j} \frac{\partial K}{\partial x_{j}}=\frac{\partial}{\partial x_{j}}\left(\frac{\mu_{t}}{\sigma_{K}} \frac{\partial K}{\partial x_{j}}\right)+\mu_{t} \frac{\partial v_{j}}{\partial x_{i}}\left(\frac{\partial v_{i}}{\partial x_{j}}+\frac{\partial v_{j}}{\partial x_{i}}\right)-\rho \varepsilon \\
\rho v_{j} \frac{\partial \varepsilon}{\partial x_{j}}=\frac{\partial}{\partial x_{j}}\left(\frac{\mu_{t}}{\sigma_{\varepsilon}} \frac{\partial \varepsilon}{\partial x_{j}}\right)+C_{1} \mu_{t} \frac{\varepsilon}{K} \frac{\partial v_{j}}{\partial x_{i}}\left(\frac{\partial v_{i}}{\partial x_{j}}+\frac{\partial v_{j}}{\partial x_{i}}\right)-C_{2} \frac{\varepsilon}{K} \rho \varepsilon
\end{gathered}
$$

In the above equations the effective viscosity is determined from $\mu_{e f f}=\mu_{0}+\mu_{t}$, where $\mu_{0}$ is the laminar viscosity and $\mu_{t}$ is the turbulent viscosity. Besides, $\mu_{t}$ is obtained from $\mu_{t}=\rho C_{\mu} K^{2} / \varepsilon$, where $K$ and $\varepsilon$ are calculated from Equations (2)-(3). Besides, the values of $\sigma_{K}, \sigma_{\varepsilon}, C_{1}, C_{2}$ and $C_{\mu}$ are 1.0, 1.3, 1.44, 1.92 and 0.09, respectively. Boundary conditions for $K$ and $\varepsilon$ at the inlet nozzles are calculated from [11] assuming that the entry jet and at the outlet flow profiles are flat:

$$
\begin{gathered}
K_{i n}=0.01 U_{i n}^{2} \\
\varepsilon_{i n}=\frac{2 K_{i n}^{3 / 2}}{D_{n}}
\end{gathered}
$$


where $U_{i n}$ and $D_{n}$ are the inlet nominal velocity and the nozzle diameter, respectively.

The Volume of Fluid (VOF) model is used here to model the multiphase flow; it is based on the assumption that two or more phases are not interpenetrating. The tracking of the interface between the phases is accomplished by solving the continuity equation for each phase [12]:

$$
\frac{\partial \alpha_{i}}{\partial t}+\boldsymbol{v} \cdot \nabla \alpha_{i}=0
$$

where $\alpha_{i}$ is the volume fraction of the $i^{\text {th }}$ phase.

\section{Computer Simulations}

The dimensions of the considered BOF, which correspond to an industrial furnace of 150 metric tons of capacity, are shown in Table 1. In order to avoid excessive CPU time, an isothermal two-dimensional system is assumed. The coupled Navier-Stokes equations, the continuity equation, the turbulence model and the VOF model were numerically solved using a commercial CFD software. Transient isothermal two-dimensional computer simulations were carried out using a time step of $0.0001 \mathrm{~s}$ and a mesh consisting of 14,075 trilateral cells. For Pressure-velocity coupling, the Pressure Implicit Splitting Operations (PISO) algorithm was employed. For discretization of the momentum equation, the Pressure Staggering Option (PRESTO) scheme was selected.

Three nozzles were assumed at the BOF bottom: one centered and two laterals. Then, four blowing conditions of nitrogen jets were considered in the computer runs: 1) top blowing (top, three jets are blown), 2) combined blowing using just the bottom centered nozzle (combined-center, four jets are blown), 3) combined blowing using the bottom lateral nozzles (combined-lateral, five jets are blown), and 4) full combined blowing using the two top and the three bottom nozzles (full combined, six jets are blown). The total integration time was $7 \mathrm{~s}$. Table 2 shows the values of the operating parameters and the physical properties of molten slag and nitrogen employed in the computer simulations. These values correspond to an industrial converter of 150 metric tons of capacity [13].

Table 1. Dimensions of the BOF.

\begin{tabular}{cc}
\hline ITEM & VALUE \\
Height & $7.2 \mathrm{~m}$ \\
Diameter & $4.8 \mathrm{~m}$ \\
Top lance diameter & $0.2 \mathrm{~m}$ \\
Nozzle diameter & $0.043 \mathrm{~m}$ \\
Number of lance nozzles & 3 \\
Number of bottom nozzles & 3 \\
\hline
\end{tabular}

Table 2. Operating parameter and physical properties.

\begin{tabular}{cc}
\hline PARAMETER & VALUE \\
\hline Top jet velocity & $333 \mathrm{~m} / \mathrm{s}$ \\
Bottom jet velocity & $50 \mathrm{~m} / \mathrm{s}$ \\
Lance height & $3 \mathrm{~m}$ \\
Jet exit angle & 12 degrees \\
Slag viscosity & $0.01 \mathrm{~kg} /(\mathrm{m} \cdot \mathrm{s})$ \\
Slag density & $2500 \mathrm{~kg} / \mathrm{m}^{3}$ \\
Molten slag depth & $0.5 \mathrm{~m}$ \\
Nitrogen viscosity & $1.663 \times 10^{-5} \mathrm{~kg} /(\mathrm{m} \cdot \mathrm{s})$ \\
Nitrogen density & $1.138 \mathrm{~kg} / \mathrm{m}^{3}$
\end{tabular}




\section{Results and Comments}

Results are reported and analyzed using the obtained phase distributions inside the BOF vessel. In the subsequent figures, the red phase represents the molten slag whereas the blue one represents the gaseous nitrogen. Figure 1 shows the coordinate axis and the velocity and reference vectors corresponding to the four blowing conditions. In this figure, red vectors correspond to the top and bottom jets. It is observed that the bottom jets alter the seemingly symmetrical internal flow caused by the nitrogen top jet.

In Figure 2 and Figure 3 are depicted the time evolution of the phase distribution for the top and full combined blowing conditions during the earliest fraction of seconds from the blowing inception. For top blowing, the momentum of the nitrogen jet is transferred to the molten slag and produces a gradual deformation of the slag surface. For a time of $0.4 \mathrm{~s}$, Figure 2 shows that molten slag exhibits an absence of drop formation. For full combined blowing, bubbles of nitrogen in the molten slag are formed due to the bottom jets. These bubbles grow in size as time proceeds, and finally bubble breakage with drop formation occurs. In both cases, neither top blowing nor full combined blowing exhibit slag splashing yet.

Generally speaking, the depth of the cavity formed in the molten slag depends on the momentum of the nitrogen jet and the number of operating jets. In its turn, the jet momentum depends on the nitrogen mass flow rate and the velocity: as the jet velocity is increased, the slag splashing is increased. Low jet velocity promotes the

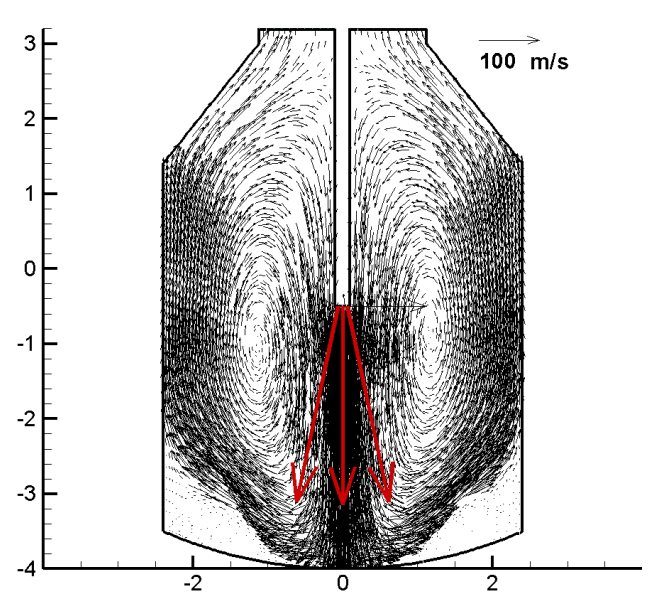

(a)

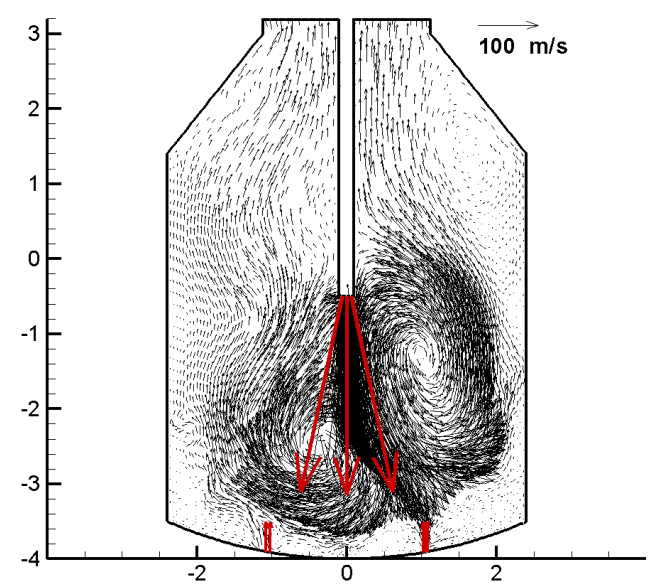

(c)

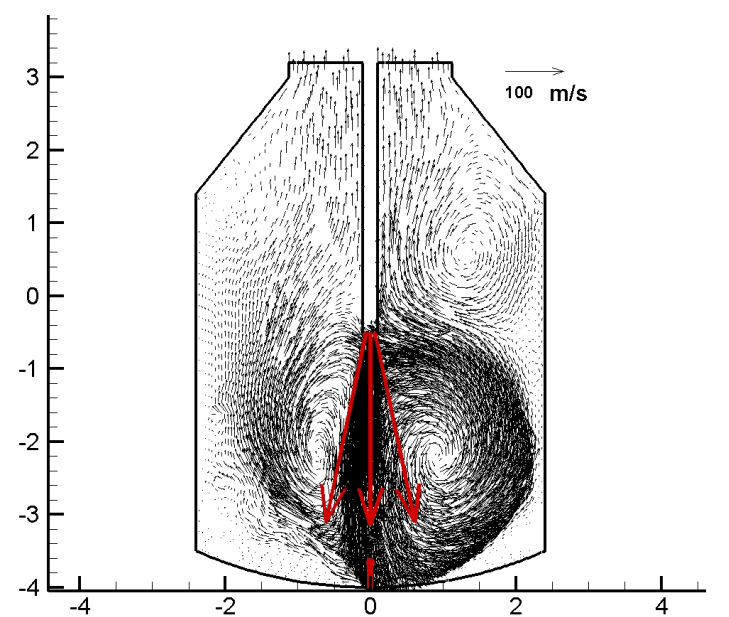

(b)

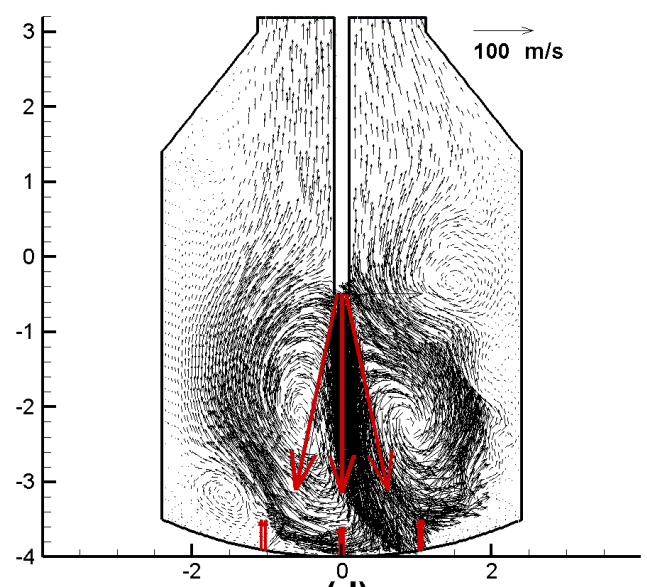

(d)

Figure 1. Velocity vectors after $1 \mathrm{~s}$ from the start of blowing. Blowing condition: (a) top, (b) combined-center, (c) combined-lateral, (d) full combined. 


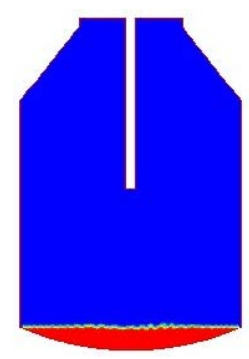

(a)

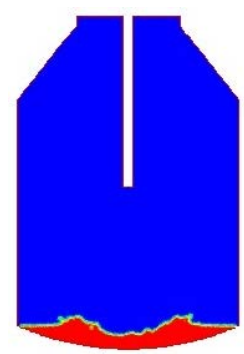

(c)

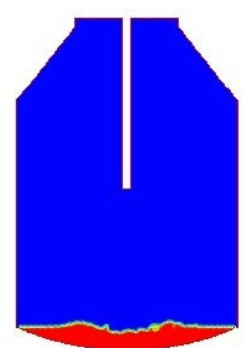

(b)

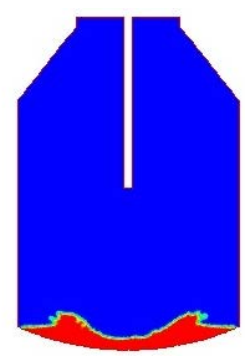

(d)

Figure 2. Time evolution of phase distributions for the top blowing. (a) 0.1 , (b) 0.2 , (c) 0.3 , (d) 0.4 s elapsed from the start of blowing.

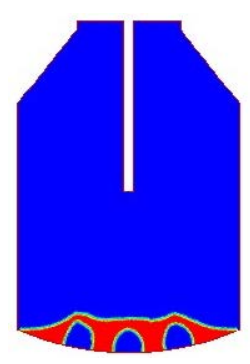

(a)

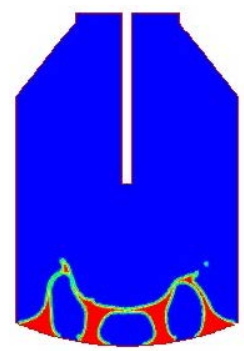

(c)

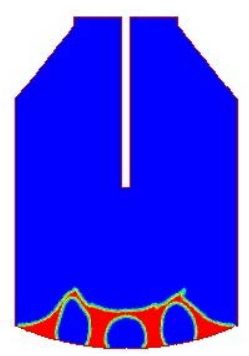

(b)

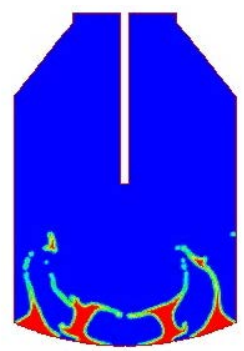

(d)

Figure 3. Time evolution of phase distributions for the full combined blowing. (a) 0.1 , (b) 0.2 , (c) 0.3 , (d) 0.4 s elapsed from the start of blowing.

stirring of the slag and the wash coating mechanism dominates, whereas high jet velocity generates high shearing forces and high drop generation; in this case the ejection mechanism is dominant [7].

Figure 4 shows the phase distributions for the four blowing conditions corresponding to $5 \mathrm{~s}$ of elapsed from the start of blowing. Slag splashing and ejection coating mechanism are observed in the four cases, however the intensity of these phenomena is increased as the number of blown nitrogen jets grows. On the contrary, slag 
coating by the washing mechanism decreases as the blown jets are increased. The amount of momentum transferred from the blown jets to the molten slag explains the aforementioned behavior: more nitrogen jets impacting the molten slag means more drop formation and the drops are ejected higher.

Figure 5 yields more conclusive results. Here, the top blowing condition is directly compared with the full combined one for $7 \mathrm{~s}$ of elapsed time. Drop forming and the height reached by slag drops are greater in the case of full combined blowing than in the case of top blowing. A mass balance made in the converter shows that the corresponding nitrogen mass flow rates exiting the BOF vessel are 48.4 and $57.3 \mathrm{~kg} / \mathrm{s}$, respectively, which explains the difference in drop formation, slag splashing and height reached by of drops. Then, it is expected that slag coating will be greater for full combined blowing than for top blowing.

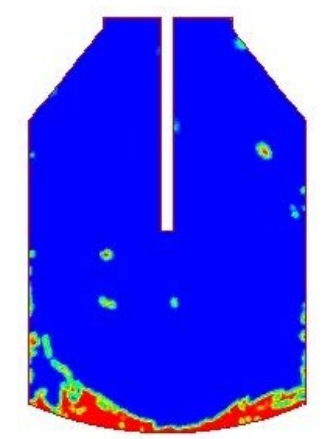

(a)

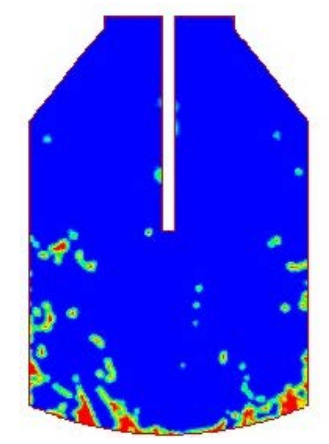

(c)

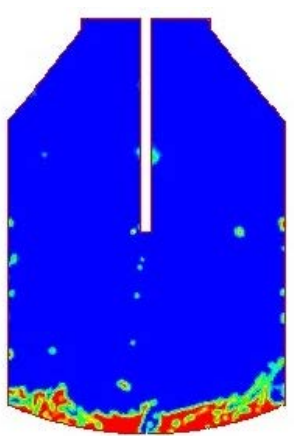

(b)

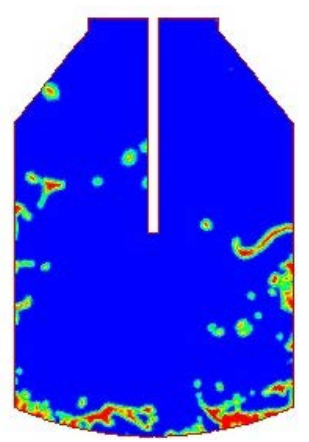

(d)

Figure 4. Phase distributions after $5 \mathrm{~s}$ from the start of blowing. Blowing condition: (a) top, (b) combined-center, (c) combined-lateral, (d) full combined.

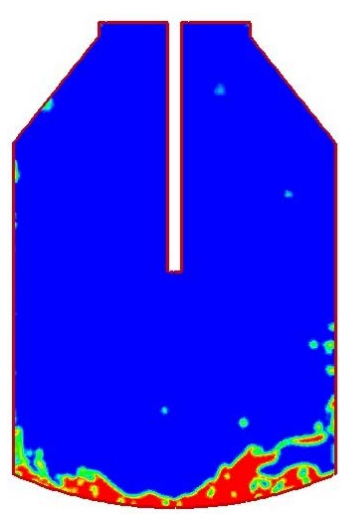

(a)

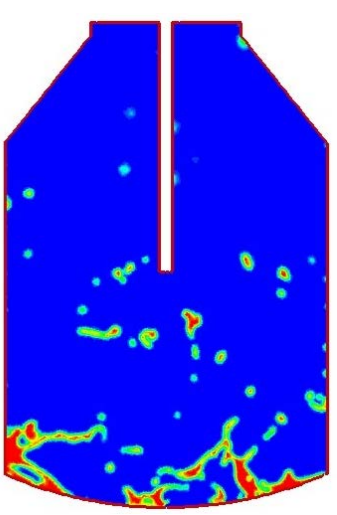

(b)

Figure 5. Phase distributions after $7 \mathrm{~s}$ from the start of blowing. Blowing condition: (a) top, (b) full combined. 


\section{Conclusions}

Slag splashing in a basic oxygen furnace is modeled using the Computational Fluid Dynamics technique. Particularly, the influence of the blowing condition on drop formation of molten slag and height reached by drops is studied. From the computer simulation results the following conclusions arise:

1) Transfer of momentum of the nitrogen jets to the molten slag causes drop formation and slag splashing.

2) Bottom blowing causes nitrogen bubbles in the molten slag which promotes fast drop formation.

3) Drop formation is enhanced as the number of nitrogen jets entering the furnace vessel is increased.

4) Full combined blowing provides greater slag splashing and drop height than conventional top blowing.

\section{References}

[1] Messina, C.J. and Paules, J.R. (1996) The Worldwide Status of BOF Slag Splashing Practices and Performance. Steelmaking Conference Proceedings, Pittsburgh, 153-155.

[2] Galiullin, T.R., Protopopov, E.V., Sokolov, V.V. and Chernyatevich, A.G. (2008) Gas-Jet Conditions in the Slag Coating of Oxygen-Converter Linings. Steel in Translation, 38, 97-100. http://dx.doi.org/10.3103/S0967091208020010

[3] Peaslee, K.D. (1996) Physical Modelling of Slag Splashing in the BOF. Iron and Steel Engineer, 73, 33-37.

[4] Mills, K.C., Su, Y., Fox, A.B., Li, Z., Thackray, R.P. and Tsai, H.T. (2005) A Review of Slag Splashing. ISIJ International, 45, 619-633. http://dx.doi.org/10.2355/isijinternational.45.619

[5] Luomala, M.J., Fabritius, T.M.J., Virtanen, E.O., Siivola, T.P., Fabritius, T.L.J., Tenkku, H. and Härkki, J.J. (2002) Physical Model Study of Selective Slag Splashing in the BOF. ISIJ International, 42, 1219-1224. http://dx.doi.org/10.2355/isijinternational.42.1219

[6] Peaslee, K.D. and Chen, W. (2004) Important Factors for Effective Slag Splashing. CIM Conference, Edmonton, 9-12 May 2004, 191-202.

[7] Barron, M.A. and Hilerio, I. (2011) Numerical Analysis of Slag Splashing in a Steelmaking Converter. Computer Technology and Application, 2, 828-834.

[8] Barron, M.A., Medina, D.Y. and Hilerio, I. (2013) CFD Analysis of Influence of Slag Viscosity on the Splashing Process in an Oxygen Steelmaking Converter. Modeling and Numerical Simulation of Material Science, 3, 90-93. http://dx.doi.org/10.4236/mnsms.2013.33012

[9] Barron, M.A., Medina, D.Y., Hilerio, I. and Plascencia, G. (2014) Influence of the Slag Density on the Splashing Process in a Steelmaking Converter. ISRN Metallurgy, 2014, Article ID: 525706.

[10] Bird, R.B., Stewart, W.E. and Lightfoot, E.N. (2002) Transport Phenomena. 2nd Edition, Wiley, New York.

[11] Solorio-Diaz, G., Morales, R.D., Palafox-Ramos, J., Garcia-Demedices, L. and Ramos-Banderas, A. (2004) Analysis of Fluid Flow Turbulence in Tundishes Fed by a Swirling Ladle Shroud. ISIJ International, 44, 1024-1032. http://dx.doi.org/10.2355/isijinternational.44.1024

[12] Hirt, C.W. and Nichols, B.D. (1981) Volume of Fluid (VOF) Method for the Dynamics of Free Boundaries. Journal of Computational Physics, 39, 201-225. http://dx.doi.org/10.1016/0021-9991(81)90145-5

[13] Garnica, P.G., Morales, R.D. and Rodriguez, N.U. (1994) Improving the Operation Technology of the BOF at SICARTSA. Proceedings of the 77th Steelmaking Conference, Chicago, 20 March 1994, 189-197. 